\title{
Injury of Neoplastic Cells by Murine Macrophages Leads to Inhibition of Mitochondrial Respiration
}

\author{
Donald L. Granger, Read R. Taintor, James L. Cook, and John B. Hibbs, Jr., \\ Veterans Administration Medical Center and Department of Medicine, \\ Division of Infectious Diseases, University of Utah Medical Center, \\ Salt Lake City, Utah 84132
}

\begin{abstract}
A B S T R A C T Cytotoxic activated macrophages (CM) inhibited the growth of neoplastic L1210 cells in vitro but L1210 cell death was minimal to nonexistent. L1210 cells injured by CM were separated from macrophages and studied in an isolated system. CM-injured L1210 cells had an absolute requirement for glucose or another glycolyzable hexose (mannose or fructose) for at least $40 \mathrm{~h}$ after removal from macrophages. If the culture medium lacked sufficient concentration of one of these sugars, CM-injured L1210 cells died within $4 \mathrm{~h}$. Uninjured L1210 cells cultured alone or with peptonestimulated macrophages had no such requirement and maintained complete viability in hexoseless medium. The hexose requirement of CM-injured L1210 cells could not be fulfilled by other naturally occurring monosaccharides, glucose or mannose derivatives, or substrates that can be oxidized by mitochondria. The concentration requirements for glucose, mannose, and fructose by CM-injured L1210 cells correlated with the concentrations required to support maximal glycol-
\end{abstract} ysis of these sugars by other murine ascites cells. A concentration of 2-deoxy-D-glucose which completely inhibited L1210 cell glycolysis also completely prevented the ability of glucose or mannose to maintain viability of CM-injured L1210 cells.

Interaction with CM led to inhibition of L1210 cell mitochondrial oxidative phosphorylation. This was supported by the findings that: (a) CM-injured L1210 cells had no Pasteur effect; their rate of aerobic glycolysis was the same as the rate of anaerobic glycolysis of uninjured L1210 cells. (b) Endogenous respiration of CM-injured L1210 cells was $15 \%$ of normal. Maximal inhibition of uninjured L1210 cell respiration by a specific mitochondrial poison (oligomycin) was nearly the same ( $13 \%$ of normal). It followed that CM-injured L1210 cells required hexose for chemical energy production via the glycolytic pathway. CM-induced mito-

Received for publication 27 July 1979 and in revised form 1 October 1979. chondrial injury occurred in five other neoplastic cell lines tested.

\section{INTRODUCTION}

Neoplastic cells are injured upon contacting macrophages that have differentiated to an "activated"1 state. Macrophage-induced injury is manifested by cytostasis and in some instances cytolysis of the affected target cells (1). The biochemical mechanism(s) by which this injury is mediated is not completely understood and several possibilities exist (3-6). By studying a murine leukemia cell line (L1210) which stops dividing but does not die after macrophage-induced injury in vitro, we have found that mitochondrial energy metabolism is severely inhibited. This is based on the following measurements: $(a)$ Macrophage-injured L1210 cells rapidly die unless substrate for glycolysis is present in their environment. (b) Macrophage injury causes L1210 cell aerobic glycolysis to increase such that the Pasteur effect is lost. (c) Mitochondrial oxygen consumption of macrophage-injured L1210 cells is inhibited to such an extent that one can predict that oxidative phosphorylation is markedly reduced. This cellular injury has the potential to inhibit neoplastic cell growth and may lead to death of certain neoplastic cells.

\section{METHODS}

Mice. Female C3H/HeN (Sprague-Dawley, Madison, Wisc.), ICR (University of Utah Vivarium, Salt Lake City, Utah), and male Swiss Webster (Rocky Mountain Laboratory, Hamilton, Mont.) mice 8-12-wk old were used as sources

\footnotetext{
${ }^{1}$ Recently the impreciseness of the term "activated macrophage" was discussed (2). It was suggested that macrophages be termed: $(a)$ according to their specific functional properties and $(b)$ according to the mediators which were used to induce their functional state. In keeping with these suggestions macrophage terminology used in this report is defined in the methods section (see "Macrophage-tumor cell cocultures").
} 
of macrophages. The cytotoxic effect of macrophages from the different mouse strains was the same.

Reagents. Except where noted, monosaccharides and monosaccharide derivatives were obtained from the same supplier (Pfanstiehl Labs., Inc., Waukegan, Ill.). Nucleotide sugars, lactic dehydrogenase, $\mathrm{NAD}^{+}$, antimycin $\mathrm{A}$, and oligomycin were purchased from Sigma Chemical Co., St. Louis, Mo. Pronase (grade B) was obtained from Calbiochem-Behring Corp., American Hoechst Corp., San Diego, Calif. Components used to prepare culture medium were obtained from Flow Laboratories, Inc., Rockville, Md. Bacterial endotoxin (ET), ${ }^{2}$ an aqueous ether extract of Salmonella enteritidis was kindly supplied by Dr. Edgar Ribi, Rocky Mountain Laboratory. Macrophage activating factor (MAF) secreted into culture medium by mouse peritoneal exudate cells (PEC) treated with sodium periodate was prepared by a modification of the method of Bressler (7).

Culture media. A major variable in the experiments reported here was the concentration of glucose (or other sugars) in the culture medium. To control this variable we prepared Dulbecco's modified Eagle's medium (DMEM) with all components except for glucose. To this filter-sterilized medium the following was added: sodium pyruvate, $5 \mathrm{mM}$ final concentration; Hepes buffer, $20 \mathrm{mM}$; penicillin G $100 \mathrm{U} / \mathrm{ml}$; and streptomycin, $100 \mu \mathrm{g} / \mathrm{ml}$. This glucose-free medium was designated DMEM minus glucose (G) (DMEM-G). Where noted glucose, other monosaccharides or substrates were added to DMEM-G to the final concentrations shown (DMEM + additive). Culture media were supplemented with human serum from normal donors or, for medium completely lacking glucose, human serum dialyzed ( $\mathrm{H}-45$ dialysis tubing, Arthur H. Thomas Co., Philadelphia, Pa.) against phosphatebuffered saline, $\mathrm{pH}$ 7.4.

Target cell lines. For most experiments a methylcholanthrene-induced murine (DBA/2) lymphoblastic leukemia cell line (L1210) was used (8). L1210 cells were maintained in suspension culture by serial in vitro passage in $D M E M+G$, $15.5 \mathrm{mM}$, with $10 \%$ fetal bovine serum (Grand Island Biological Co., Grand Island, N. Y.). In vitro generation time is $12 \mathrm{~h}$ and is constant between cell densities of $5 \times 10^{4}$ and 1 $\times 10^{6} / \mathrm{ml}$. L1210 cells for cytotoxicity experiments were always 3-d log-phase cultures. Characteristics of other target cell lines are listed in Table IV. Except for L10 these cell lines were also cultured in vitro as described above.

Macrophage-tumor cell cocultures. Macrophages of differing cytotoxic potential were used. Stimulated macrophages (SM) were from mice injected intraperitoneally with $1 \mathrm{ml}$ 10\% proteose peptone (Difco Laboratories, Detroit, Mich.) three $d$ before harvest. Noncytotoxic activated macrophages (NCM) came from mice infected intraperitoneally with 0.2 mg Mycobacterium bovis, strain BCG, 17-22 d before harvest and injected with $1 \mathrm{ml}$ peptone $3 \mathrm{~d}$ before harvest. NCM were generally noncytotoxic unless an additional in vitro differentiation stimulus was provided (9). 20-200 $\mathrm{ng} / \mathrm{ml} \mathrm{ET}$, added to the culture medium, was used for this purpose. These cells were termed cytotoxic activated macrophages (CM). In some experiments MAF instead of ET was added to the culture medium, $10 \% \mathrm{vol} / \mathrm{vol}$, to induce differentiation of $\mathrm{NCM}$ to the cytotoxic state (7). These macrophages were designated CM (MAF). The potential effect of ET and MAF on target

\footnotetext{
${ }^{2}$ Abbreviations used in this paper: $\mathrm{CM}$, cytotoxic activated macrophages; 2DG, 2-deoxy-D-glucose; DMEM-G, Dulbecco's modified Eagle's medium without glucose; ET, endotoxin; G, glucose; MAF, macrophage activating factor; NCM, noncytotoxic activated macrophages; PEC, peritoneal exudate cells; PRC, pronase releasable counts; SM, stimulated macrophages; TRC, total releasable counts.
}

cells was controlled by incubating target cells alone in medium with or without ET or MAF at the same concentration used to activate macrophages.

Except where noted, incubation conditions were: $37^{\circ} \mathrm{C}$ in humidified $95 \%$ air, $5 \% \mathrm{CO}_{2}$ atmosphere. Macrophage monolayers were prepared from PEC by adherence to plastic culture vessels. Because differently sized culture vessels from the same manufacturer were used $(3524,3506,3100$, Costar, Cambridge, Mass.), PEC, target cells, and medium volume were always added at the same cell number or volume to surface area ratio. Under these conditions macrophage cytotoxicity was the same with the differently sized vessels. For ease of presenting the data, the number of PEC and target cells is always given as the cell number per milliliter of medium. Medium volume was always $0.5 \mathrm{ml} / \mathrm{cm}^{2}$ culture surface area. Unless stated otherwise $4 \times 10^{6} \mathrm{PEC} / \mathrm{ml} \mathrm{DMEM}+\mathrm{G}$, $15.5 \mathrm{mM}$, were allowed to adhere by incubation for $1 \mathrm{~h}$. Then nonadherent $\mathrm{PEC}$ were removed by repeated aspiration rinsing with phosphate-buffered saline using a Pasteur pipette. This procedure resulted in confluent monolayers of adherent mononuclear cells with very few nonadherent cells remaining. Except where noted, washed log-phase L1210 cells, 2 $\times 10^{5} / \mathrm{ml}$ final density, were added to macrophage monolayers in DMEM + G, $15.5 \mathrm{mM}$, with $10 \%$ human serum with or without ET or MAF.

Cytotoxicity measured by cell counting. In some experiments viable L 1210 cells were counted at the beginning and at various times after incubation alone or with macrophages. This was done by adding trypan blue $(0.1 \mathrm{ml}$ of a $0.4 \% \mathrm{wt} / \mathrm{vol}$ stock solution $/ \mathrm{ml}$ medium) and suspending L 1210 cells by repeated aspiration with a Pasteur pipette and then counting viable L1210 cells in a hemocytometer.

Other experiments involved two incubations: $(a)$ incubation of L1210 cells with macrophages (first incubation), and (b) a second incubation of L1210 cells separated from macrophages, washed by centrifugation $\left(4^{\circ} \mathrm{C}, 250 \mathrm{~g}\right)$ and reincubated in fresh medium for an additional period (second incubation). Cell counts were made at three times during a single experiment: $(a)$ at the time of addition of L1210 cells to macrophages, $(b)$ between the first and second incubations, $(c)$ at the end of the second incubation. Experiments involving two incubations were done as follows. After the first incubation L1210 cells were removed from macrophage monolayers by repeated rinsing with $\mathrm{DMEM}-\mathrm{G}$. Using $\left[{ }^{3} \mathrm{H}\right]$ thymidine-labeled L1210 cells it was found that $<1 \%$ of the total counts remained with macrophages after removal of L1210 cells by this procedure. Removed L1210 cells were washed three times with cold DMEM-G $\left(4^{\circ} \mathrm{C}, 250 \mathrm{~g}\right)$ and resuspended at $2 \times 10^{5}$ cells $/ \mathrm{ml}$ for the second incubation. Second incubation medium was always DMEM-G, with or without glucose or other substrates, with $2 \%$ dialyzed human serum.

A minimum of three counts were made on all cell suspensions. Greater than 100 cells were counted for an individual determination unless viability was very low in which case viable target cells in all squares of both sides of a hemocytometer were counted. The large size and distinctive morphology of L1210 cells readily distinguished them from PEC removed with L1210 cells; hence, their numbers could be accurately quantitated. All counts were expressed as the mean number of viable L1210 cells per milliliter.

Quantitation of $\mathrm{L} 1210$ cell death by $\left[{ }^{3} \mathrm{H}\right]$ thymidine release. The total amount of label in removed, washed L1210 cells at the beginning of the second incubation was determined by lysing aliquots of cells with sodium dodecyl sulfate and comparing this to the amount of label released into the culture medium during the second incubation. We found that dead L1210 cells, as determined by trypan blue staining, did not release any more $\left[{ }^{3} \mathrm{H}\right]$ thymidine into the medium than did 
viable cells. Microscopically dead L1210 cells retained their spherical shape and their nuclei were observed to be intact and trypan blue positive. This was observed previously with murine lymphoma cells killed by antibody and complement (10). It was shown that treatment with pronase or trypsin, led to dissolution of the dead cells and release of $\left[{ }^{14} \mathrm{C}\right]$ thymidine into the medium $(10,11)$. Enzyme treatment did not cause release of label from viable cells. We tested the effect of pronase on release of $\left[{ }^{3} \mathrm{H}\right]$ thymidine from $\mathrm{L} 1210$ cells and found, likewise, that it did not cause release from viable cells and that it did cause release from dead cells. The amount of $\left[{ }^{3} \mathrm{H}\right]$ thymidine released upon pronase treatment correlated with viability counts.

With these details in mind log-phase L1210 cells at $\sim 10^{5}$ cells $/ \mathrm{ml}$ were labeled with $\left[6{ }^{3} \mathrm{H}\right]$ thymidine, $0.2 \mu \mathrm{Ci} / \mathrm{ml}$ culture medium (sp act $=10 \mathrm{Ci} / \mathrm{mmol}$, New England Nuclear, Boston, Mass.), for $24 \mathrm{~h}$ and then washed three times and added to macrophages. After the first incubation L1210 cells were separated as described above, washed three times with $D M E M-G$, and resuspended in medium for the second incubation. At this time the total counts in the cell suspension (total releasable counts [TRC]) was determined by adding $0.5-\mathrm{ml}$ aliquots to $20-\mathrm{ml}$ glass scintillation vials containing $0.1 \mathrm{ml}$ sodium dodecyl sulfate $(1.4 \% \mathrm{wt} / \mathrm{vol})$ to lyse the cells. For the second incubation labeled L1210 cells at $2 \times 10^{5} / \mathrm{ml}$ were cultured in 16-mm Diam tissue culture wells (Costar $3524)$ each well containing a $1-\mathrm{ml}$ cell suspension $(0.5 \mathrm{ml}$ medium $\left./ \mathrm{cm}^{2}\right)$. At the beginning or at times thereafter during the second incubation $0.2 \mathrm{ml}$ pronase stock solution (stored frozen at $15 \mathrm{mg} / \mathrm{ml}$ in $0.85 \% \mathrm{NaCl}$ ) was added to each well. After a 15-min incubation at room temperature the plates were centrifuged (10 min at $250 \mathrm{~g}$ ) and $0.6 \mathrm{ml}$ of supernatant medium was carefully removed from each well and added to a scintillation vial for counting. These samples measured the amount of label released into the medium upon treatment with pronase (pronase releasable counts [PRC]), which is a measure of dead L1210 cells in the suspension. Data are expressed as the percent $\left[{ }^{3} \mathrm{H}\right]$ thymidine released for the second incubation and were calculated by:

\section{$\left[{ }^{3} \mathrm{H}\right]$ thymidine released $(\%)=[\mathrm{PRC} / \mathrm{TRC}] \cdot 100$,}

the PRC sample being taken at the end of the second incubation. In some experiments the percent $\left[{ }^{3} \mathrm{H}\right]$ thymidine released is given for the beginning and at various times during the second incubation. These data were calculated using the same formula for PRC samples taken at the times shown. The percent $\left[{ }^{3} \mathrm{H}\right]$ thymidine released at the beginning of the second incubation was always small (usually $<10 \%$ ) and therefore was not always included in the data presented. In addition for each experiment the percent $\left[{ }^{3} \mathrm{H}\right]$ thymidine released during the first incubation was also determined. This was calculated by:

\section{$\left[{ }^{3} \mathrm{H}\right]$ thymidine released $(\%)=\left[\left(\mathrm{TRC}^{\prime}-\mathrm{TRC}\right) / \mathrm{TRC}^{\prime}\right]$}

$$
\cdot 100+[\mathrm{PRC} / \mathrm{TRC}] \cdot 100,
$$

where $\mathrm{TRC}^{\prime}=$ total releasable counts in L1210 cells added to macrophges at the beginning of the first incubation and $\mathrm{PRC}=$ pronase releasable counts at the beginning of the second incubation. The first term of the equation equals the loss of $\left[{ }^{3} \mathrm{H}\right]$ thymidine during the first incubation as a result of spontaneous release and lysis of L1210 cells. The second term measures dead but intact cells after the first incubation. Percent released in each experimental group is the mean of at least triplicate samples. All samples were counted (model LS-330, Beckman Instruments, Inc., Fullerton, Calif.) in 10 $\mathrm{ml}$ of an emulsifying scintillation cocktail (Aquasol, New
England Nuclear). Counting efficiency was monitored by the sample channels ratio method, both channels being counted to $\leq 2 \%$ error. Of various additions to the assay, none caused significant change in counting efficiency.

Glycolysis. Glycolysis rates were determined by measuring lactic acid produced under constant incubation conditions. L1210 cells incubated alone or with macrophages were removed, washed three times with DMEM-G, and then resuspended at $\sim 2 \times 10^{5}$ cells $/ \mathrm{ml}$ in $\mathrm{DMEM} \pm \mathrm{G}$ or other sugars with $2 \%$ dialyzed human serum. Glycolysis incubations were performed at $37^{\circ} \mathrm{C}$ with constant shaking at 140 oscillations $/ \mathrm{min}$ in 10 - $\mathrm{ml}$ glass Erlenmeyer flasks ( $3.5 \mathrm{ml} / \mathrm{flask}$ ) under $95 \%$ air, $5 \% \mathrm{CO}_{2}$ (aerobic glycolysis) or $95 \% \mathrm{~N}_{2}, 5 \% \mathrm{CO}_{2}$ (anaerobic glycolysis) atmosphere. For anaerobic incubations flasks were placed in 3-liter stainless steel gas-tight chambers and gased with $100 \% \mathrm{~N}_{2}$. Each chamber contained one hydrogen generator envelope (Becton, Dickinson Medical Systems, Becton, Dickinson \& Co., Waltham, Mass.) to remove traces of $\mathrm{O}_{2}$ present in commercially supplied $\mathrm{N}_{2}$ tanks. Under these conditions $\mathrm{CO}_{2}$ generated from one envelope stabilized DMEM-G, pH at $7.5\left(\sim 5 \% \mathrm{CO}_{2}\right)$. Gas samples removed from the chambers into an air-tight syringe showed $<0.4 \% \mathrm{O}_{2}$ present not excluding the small amount of air in the needle attached to the sampling syringe. Methylene blue indicator strips were consistently white upon opening the jars after all glycolysis incubations.

Triplicate samples were taken at $0,2,4$, and $6 \mathrm{~h}$ for lactate determinations. Glycolysis was stopped by addition of $1 \mathrm{ml}$ ice-cold $8 \%$ (wt/vol) perchloric acid to a $0.5-\mathrm{ml}$ sample. After vigorous mixing and standing at $0^{\circ} \mathrm{C}$ for $5 \mathrm{~min}$ the samples were centrifuged $\left(4^{\circ} \mathrm{C}, 3,000 \mathrm{~g}\right)$ and the supernates were assayed for lactate concentration by an enzymatic method (12). 100- $\mu$ l supernatant samples were added to tubes containing $1.4 \mathrm{ml}$ reaction mixture. Reaction mixture consisted of: 20 parts hydrazine-glycine buffer $(0.4 \mathrm{M}$ hydrazine, $1 \mathrm{M}$ glycine, pH 9.5), 40 parts $\mathrm{NAD}^{+}, 0.4 \mathrm{mg} / \mathrm{ml}$ distilled water, and 1 part lactic dehydrogenase suspension $(\sim 15 \mathrm{Wacker}$ units $/ \mathrm{ml}$ reaction mixture). The tubes were incubated at $37^{\circ} \mathrm{C}$ for $45 \mathrm{~min}$ and then absorbance at $340 \mathrm{~nm}$ was measured (model 25 spectrophotometer, Beckman Instruments, Inc.) against a blank consisting of $100 \mu \mathrm{l} 8 \%$ perchloric acid and $1.4 \mathrm{ml}$ reaction mixture. Lactate concentration was calculated from the extinction coefficient of $\mathrm{NADH}$ at $340 \mathrm{~nm}$. Lactate standards included in all assays did not vary more than $\pm 5 \%$. Data were expressed as micromoles of lactate produced per hour per $10^{5}$ cells. Triplicate cell counts, made at the end of the incubation periods, determined the cell density for calculations.

Respiration. Respiration of L1210 cells or other neoplastic target cells previously incubated alone or with macrophages was measured with a Clark oxygen electrode (model 53, Yellow Springs Instrument Co., Yellow Springs, Ohio) connected to a recorder which was calibrated over a $0-100 \%$ scale. Target cells were rinsed from macrophage monolayers in the usual way and washed three times with Krebs-Ringer phosphate buffer, $\mathrm{pH}$ 7.4. The concentrated cell suspension was drawn into a syringe and injected into the respiration vessel to give $\sim 2 \times 10^{6}$ cell $\mathrm{s} / \mathrm{ml}$ taking care not to introduce air bubbles into the chamber. Medium was air-saturated Krebs-Ringer phosphate buffer at $37^{\circ} \mathrm{C}$. Under these conditions a linear $\mathrm{O}_{2}$ consumption curve was generated in $\sim 10 \mathrm{~min}$ from which the amount of oxygen consumed was calculated. Each measurement was corrected for the atomspheric pressure in the laboratory on that day. The respiration rate was expressed as microliters of $\mathrm{O}_{2}$ consumed per hour per $10^{6}$ cells. After each respiration measurement the cell suspension was counted six times (>500 cells) and the mean cell count was used to calculate the respiration rate.

Gas chromatography. Certain monosaccharide samples 
obtained commercially were analyzed for purity by gas-liquid chromatography (5710A gas chromatograph, Hewlett-Packard Co., Palo Alto, Calif.). The method used has been published (13).

\section{RESULTS}

Characteristics of macrophage cytotoxicity for L1210 cells. This series of experiments began with the idea of testing the susceptibility of a highly malignant neoplastic cell to macrophage-induced cytotoxicity. The L1210 cell line fulfilled this requirement because $<10$ cells are lethal for syngeneic mice (14). Moreover, mice with activated macrophages in the peritoneal cavity as a consequence of Toxoplasma gondii infection were nearly as susceptible to tumor induction as were uninfected control mice (15). Also Nathan and Terry found that macrophages from Mycobacterium bovis, strain BCG-infected mice failed to inhibit the growth of L1210 cells in vitro (16). These results suggested that L1210 cells were resistant to macrophage cytotoxicity.

The results of 30 experiments are summarized in Fig. 1A. Viable L1210 cells were counted after 20 and $40 \mathrm{~h}$ cocultivation with macrophages at various stages of differentiation. L1210 cell growth was consistently uneffected by SM. NCM caused variable, partial growth inhibition of the neoplastic targets. $\mathrm{CM}$ appeared to completely inhibit L1210 cell growth; however, there was no significant cytolysis. The apparent complete cytostasis of L1210 by CM did not result from combined growth and death because the release of $\left[{ }^{3} \mathrm{H}\right]-$ thymidine from labeled L1210 cells (a measurement of cell death) cultured with $\mathrm{CM}$ was essentially the same as the release from L1210 cells cultured alone or with SM (Table I, footnote $\uparrow$ ). In addition, only rarely were trypan blue-positive L1210 cells seen after incubation with CM. The lack of CM-mediated L1210 cell lysis was of interest because other neoplastic target cells are killed during the same in vitro culture conditions (9).

Parameters of the cytotoxicity system were examined to determine whether, under certain conditions, L1210 cell death occurred. Increasing the number of PEC beyond the minimal number required for complete cytostasis did not lead to a decrease of L1210 cells below the number added at time zero (Fig. 1B). At $<3 \times 10^{6} \mathrm{PEC} / \mathrm{ml}$ the cytotoxic effect was lost. This has been studied previously for both cytostasis (17) and lysis (18) and was found to be a function of the number of effector cells per unit surface area of the culture vessel. Because macrophage cytotoxicity critically depends on direct contact with target cells (19), the macrophage monolayer must be confluent. At $1 \times 10^{6} \mathrm{PEC} / \mathrm{ml}$ the plastic surface was not covered with macrophages. In a previous study macrophages from Mycobacterium bovis, strain BCG-infected mice failed to inhibit the growth $\left(\left[{ }^{3} \mathrm{H}\right]\right.$ thymidine uptake) of L1210 cells (16). The highest number of PEC used was $5 \times 105 / \mathrm{ml}$ (extrapolating to our assay). From the results in Fig. 1B it is clear that this was an insufficient number of PEC to cause cytostasis of L1210 cells under the conditions of our assay.

A similar complete cytostatic effect was observed when the number of L1210 cells was varied by almost $1 \log _{10}$ (Fig. 1C). Again, adjusting the culture conditions toward what would ostensibly favor the macrophage cytotoxic effect (in this case by decreasing the number of L1210 cells), did not lead to a fall in the number of L1210 cells below the number added at time zero (Fig. 1C).

The concentration of ET used to differentiate NCM to the cytotoxic state was varied over a wide range (Fig. 1D). As reported previously, very small amounts of ET (in this case $2 \mathrm{ng} / \mathrm{ml}$ ) suffice (9). Again L1210 cell death, as evidenced by decreased viable cells compared to the number at time zero, did not occur as the concentration of ET was increased. The highest concentration of ET used had no effect on L1210 cell growth in the control cultures.

Search for mediators in culture medium that induce cytostasis of L1210 cells. Known mechanisms by which macrophages can inhibit replication of neoplastic cells in vitro are: $(a)$ secretion of macrophage arginase which depletes arginine from the culture medium and hence destroys an essential nutrient required for neoplastic cell growth $(20)$, and $(b)$ release of thymidine from macrophages which can inhibit DNA synthesis of selected target cells (21). The common feature of these phenomena is that cytotoxicity can be produced by the medium in which macrophages are incubated-in the former instance the medium is deficient and in the latter, it contains a soluble growth-inhibiting factor. Because L1210 cell injury by CM resulted in cytostasis but not cytolysis, we questioned whether either of these mechanisms was operative. The media from CM cultured alone or with L1210 cells for $40 \mathrm{~h}$ were removed, centrifuged to sediment any cells present, and then used to suspend fresh L1210 cells for growth curve measurements. These media supported L1210 cell growth through greater than three generations at a rate indistinguishable from fresh medium (not shown).

As a second approach to this question L1210 cells were removed from $\mathrm{CM}$ after $40 \mathrm{~h}$ cocultivation, washed three times, and then suspended in fresh medium for an additional incubation. As shown in Fig. 2 L1210 cells previously injured by $\mathrm{CM}$ failed to divide for an additional $50 \mathrm{~h}$ despite removal from $\mathrm{CM}$ and addition of a new complement of growth factors; hence, the cellular injury inflicted by CM on L1210 cells persists for many hours beyond the time it is delivered. Although replication ceases, L1210 cells maintain almost complete viability, as assessed by trypan blue exclusion, for at least $90 \mathrm{~h}$. Arginine or other growth factor de- 
A
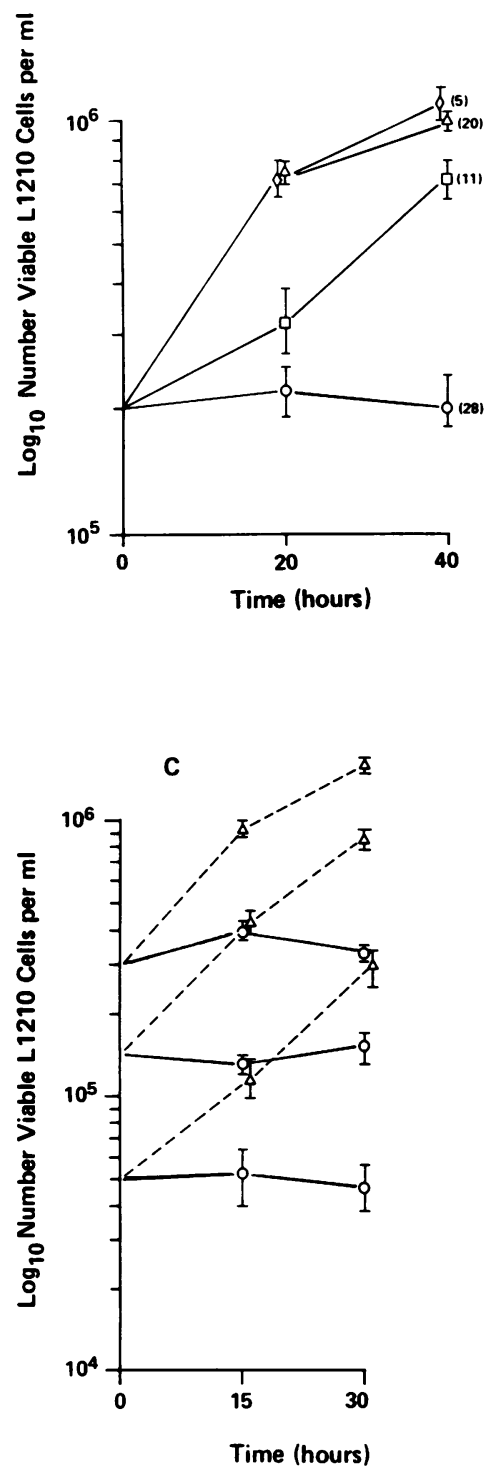

B

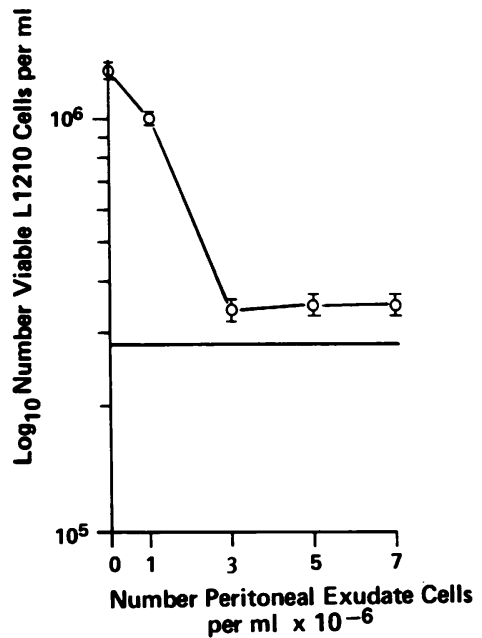

D

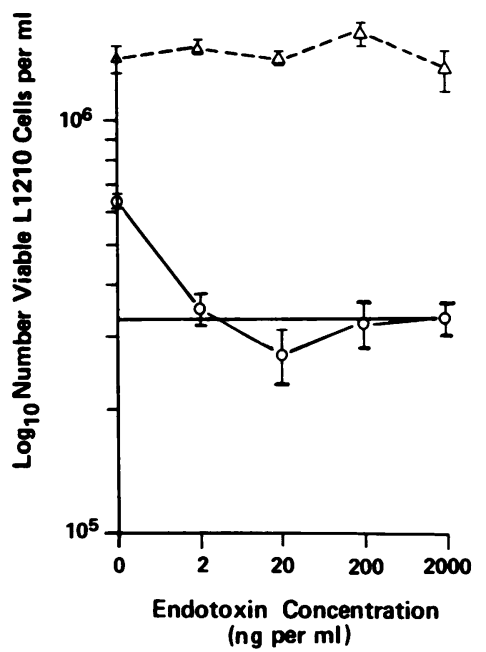

FIGURE 1 Characteristics of macrophage cytotoxicity for L1210 cells. (A) L1210 cells were incubated alone $(\triangle)$, with SM $(\diamond)$, with NCM $(\square)$, or with CM $(O)$. Points represent mean L1210 cell counts $\pm S E M$ for the number of experiments shown in parentheses. For these and subsequent experiments medium for macrophage-tumor cell cocultures was always DMEM $+\mathrm{G}, 15.5-20 \mathrm{mM}$, with $10 \%$ human serum. (B) Number of viable L1210 cells present after a 40-h incubation with increasing numbers of CM. Each point is the mean $\pm S E M$ of triplicate cell counts. Horizontal line represents the number of L1210 cells added at time zero. (C) Varying numbers of L1210 cells incubated alone $(\Delta)$, or with $C M(O)$. Each point is the mean $\pm S E M$ of quadruplicate cell counts. (D) L1210 cells incubated alone $(\triangle)$, with $\mathrm{NCM}(O$, no ET), or with CM (O) with increasing concentrations of ET. Viable L1210 cells counted at $40 \mathrm{~h}$. Each point is the mean \pm SEM of triplicate counts of viable L 1210 cells at $40 \mathrm{~h}$. Horizontal line represents the number of L1210 cells added at time zero.

pletion or a macrophage-derived toxin present in medium cannot explain these data.

L1210 cells injured by CM have a strict requirement for glucose to remain viable. When longer incubation periods were employed, almost complete death of L1210 cells cultured with CM occurred between days 3 and 4 if the number of $\mathrm{L} 1210$ cells added at time zero was $\sim 3 \times 10^{5} / \mathrm{ml}$. However, if the number of L1210 cells 


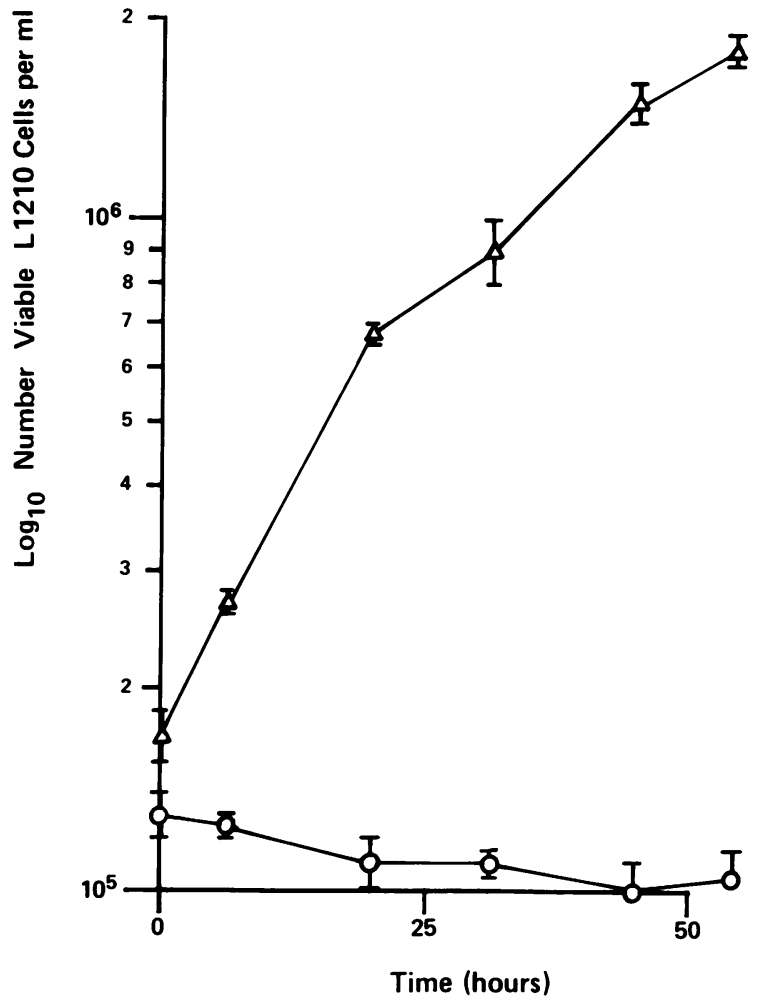

Figure 2 CM-induced L1210 cell stasis is not reversed by removing target cells from macrophages and adding fresh growth medium. L1210 cells which had been incubated with $\mathrm{CM}$ for $40 \mathrm{~h}$ were removed, washed, and reincubated for $\sim 50 \mathrm{~h}(\mathrm{O}) .(\triangle)$, uninjured L1210 cells. One-half the medium volume $(0.5 \mathrm{ml})$ was replaced with fresh medium $(10 \mathrm{mM}$ $\mathrm{DMEM}+\mathrm{G}$, with $10 \%$ human serum) each day. Each point is the mean $\pm S E M$ of triplicate cell counts.

added to $\mathrm{CM}$ was considerably less $\left(5 \times 10^{4} / \mathrm{ml}\right)$ no death occurred. This result could be explained if the target cells depleted something from the medium. With fewer target cells the depletion might have been quantitatively insufficient to cause the effect. We then began to examine the effect of adding various components of culture medium on L1210 cell death. Increasing the concentration of glucose in the medium from 15.5 to $40 \mathrm{mM}$ completely prevented the death of L 1210 cells on day 4 . Moreover, there was no detectable glucose in the medium on day 4 when L1210 cells died. It appeared that L1210 cells and CM exhausted the supply of glucose during the 4 -d culture period and this resulted in death of $\mathrm{L} 1210$ cells.

To analyze this phenomenon L1210 cells were incubated with CM for a given period with a nonlimiting glucose supply $(20 \mathrm{mM}$ under the conditions of the assay). After the first incubation target cells were removed from macrophages and reincubated in the absence of macrophages (second incubation) in a medium lacking glucose (DMEM-G with $2 \%$ dialyzed human serum). In this way the effect of adding glucose or other substrates to DMEM-G was studied. The effect of glucose on L1210 cells injured by CM (injured L1210 cells) is presented in Table I. Two methods of measuring L1210 cell death were used; both gave the same results. It is clear that L 1210 cells previously cultured with CM, whose final differentiation had been induced by either $\mathrm{ET}$ or MAF, required glucose to remain viable. Without glucose a high percentage of $\mathrm{CM}$-injured L1210 cells died (on the average $\sim 85 \%$ ). The addition of 5-10 $\mathrm{mM}$ glucose to DMEM-G completely prevented cell death as shown by both methods of measurement. Uninjured L1210 cells cultured alone or with SM (uninjured L1210 cells) had no such requirement; in fact they proliferated in the same glucose-free medium. The effect was not a result of the ET or MAF used to activate NCM because L1210 cells cultured without $\mathrm{CM}$ but with the activators remained viable when they were subsequently incubated in DMEM-G. At the end of the first incubation, when L1210 cells were removed, there were always some macrophages $(<10 \%$ of the total cells) which dislodged from the plastic surface and "contaminated" the target cell suspension. L1210 cells were "decontaminated" by three successive adherence steps in plastic dishes. This reduced contaminating macrophages to an uncountable level. Injured L1210 cell death in DMEM-G was almost the same in the original cell suspension $(87 \%)$ as in the decontaminated suspension (93\%).

Characteristics of injured L1210 cell death in $D M E M-G$. The kinetics of injured L1210 cell death in DMEM-G was measured and found to be rapid (Fig. 3A). By $2 \mathrm{~h}$ into the second incubation $75 \%$ of label was released, and by $4 \mathrm{~h},\left[{ }^{3} \mathrm{H}\right]$ thymidine release was almost maximal. Within $1 \mathrm{~h}$ of incubation in DMEM-G, CM-injured L1210 cells developed multiple small blebs at the cell surface. By $2 \mathrm{~h}$ many cells had large acentric blebs demonstrating a marked expansion of the intracellular volume (Fig. 4). Later (4-6 h) most cells appeared as shrunken spheres with indistinct margins. The development of morphologic changes after $<1 \mathrm{~h}$ in DMEM-G suggested that glucose was needed for some cellular function with a rapid turnover rate.

L1210 cells were removed from CM after first incubations of varying periods and then incubated in DMEM-G to measure cell death (Fig. 3B). By $20 \mathrm{~h}$ CM-induced injury, as measured by death in DMEM-G, was near maximal. However, after $10 \mathrm{~h}$ of cocultivation it was hardly measurable. Thus, the injury delivered to $\mathrm{L} 1210$ cells by $\mathrm{CM}$ requires a rather extended period $(20 \mathrm{~h})$ to reach maximum. This is not to say that $\mathrm{CM}$ injury is not evident by $10 \mathrm{~h}$; it is. L1210 cells removed at $10 \mathrm{~h}$ fail to grow for an additional $24 \mathrm{~h}$ in DMEM $+\mathrm{G}$ (not shown) demonstrating that injury as measured by cytostasis is present.

Fig. 2 shows that L1210 cells, removed from CM 
TABLE I

Effect of Glucose on L1210 Cell Viability after Culture with CM

\begin{tabular}{|c|c|c|c|c|c|c|c|}
\hline \multirow[b]{3}{*}{ First incubation* } & \multicolumn{7}{|c|}{ Second incubation $\downarrow$} \\
\hline & \multirow[b]{2}{*}{$\begin{array}{c}\text { Culture } \\
\text { medium } \S\end{array}$} & \multicolumn{3}{|c|}{$\begin{array}{l}\text { Cell counting assay, } \\
\text { viable } L 1210 \text { cells/ml } \cdot 10^{\text {s! }}\end{array}$} & \multicolumn{3}{|c|}{$\begin{array}{l}{\left[{ }^{3} \mathrm{H}\right] \text { thymidine release assay, }} \\
\text { \% of total counts } \$\end{array}$} \\
\hline & & $\begin{array}{l}\text { Experi- } \\
\text { ments }\end{array}$ & Time zero & $\begin{array}{c}\text { End of } \\
\text { incubation }\end{array}$ & $\begin{array}{l}\text { Experi- } \\
\text { ments }\end{array}$ & Mean & Range \\
\hline \multicolumn{8}{|c|}{$\begin{array}{l}\text { L1210 cells } \\
\text { cultured with: }\end{array}$} \\
\hline $\mathrm{CM}$ & $\begin{array}{l}\text { DMEM + G } \\
\text { DMEM - G }\end{array}$ & 13 & $1.8 \pm 0.24$ & $\begin{array}{r}2.1 \pm 0.34 \\
0.24 \pm 0.09\end{array}$ & 10 & $\begin{array}{l}15 \\
81\end{array}$ & $\begin{array}{c}9-21 \\
53-100\end{array}$ \\
\hline CM (MAF) & $\begin{array}{l}\text { DMEM + G } \\
\text { DMEM - G }\end{array}$ & 3 & $1.1 \pm 0.10$ & $\begin{array}{l}1.0 \pm 0.07 \\
0.2 \pm 0.09\end{array}$ & $\mathrm{NT}^{* *}$ & - & - \\
\hline SM & $\begin{array}{l}\text { DMEM + G } \\
\text { DMEM - G }\end{array}$ & 3 & $2.7 \pm 0.36$ & $\begin{array}{l}8.1 \pm 0.68 \\
6.3 \pm 0.96\end{array}$ & 3 & $\begin{array}{l}8 \\
9\end{array}$ & $\begin{array}{l}6-10 \\
6-10\end{array}$ \\
\hline Alone & $\begin{array}{l}\text { DMEM + G } \\
\text { DMEM - G }\end{array}$ & 6 & $2.8 \pm 0.34$ & $\begin{array}{l}8.2 \pm 1.0 \\
5.1 \pm 1.1\end{array}$ & 6 & $\begin{array}{l}16 \\
14\end{array}$ & $\begin{array}{r}11-21 \\
8-19\end{array}$ \\
\hline
\end{tabular}

* The first incubation for all experiments lasted $\sim 24 \mathrm{~h}$. Experiments in which L1210 cells cultured alone in medium without or with ET or MAF at the same concentration used to activate CM were not segregated because they all gave the same results.

For all experiments the second incubation lasted from 16 to $24 \mathrm{~h}$.

\$ Glucose (G) concentration was 5-10 mM. For these and subsequent experiments second incubation medium was always supplemented with $2 \%$ dialyzed human serum.

"Values are the mean \pm SEM for the number of experiments shown.

If Values are the means with the range for the number of experiments shown. $\left[{ }^{3} \mathrm{H}\right]$ Thymidine released during the first incubation ranged from 6 to $26 \%$ (mean $=15 \%$ ) for CM, 2-11\% (mean = 7\%) for SM, and 5-18\% (mean = $14 \%$ ) for $\mathrm{L} 1210$ cells cultured alone.

** NT $=$ not tested.
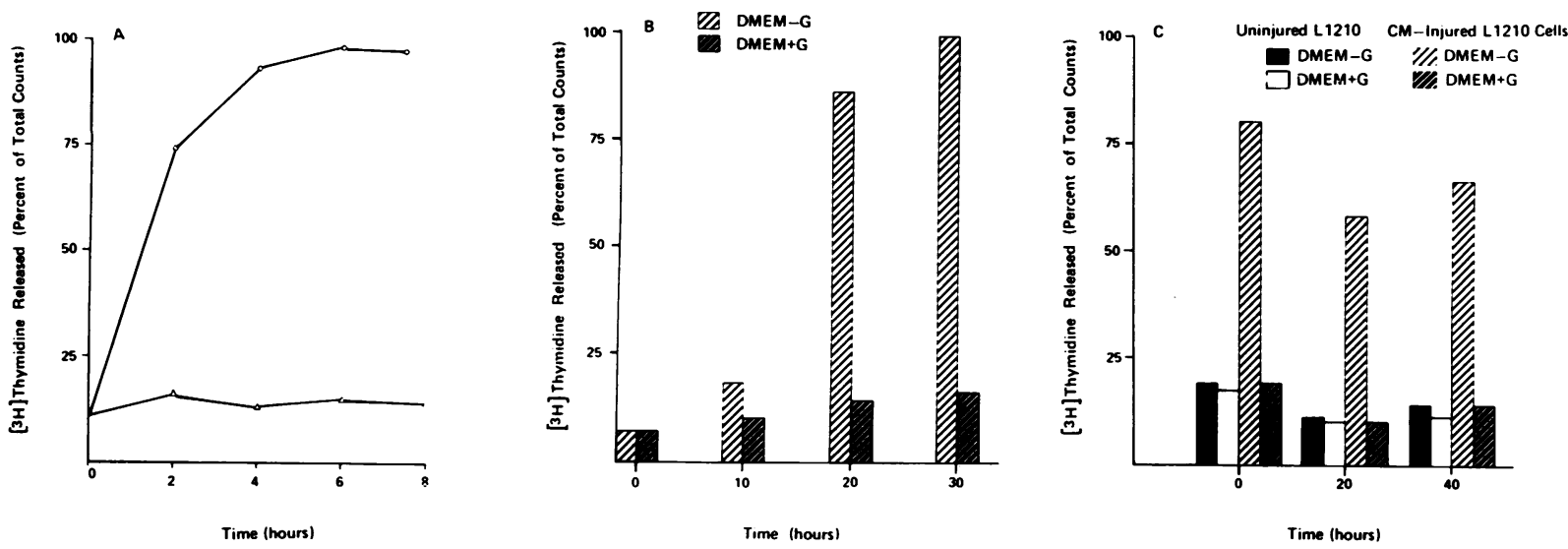

FIGURE 3 CM-injured L1210 cells require glucose to remain viable. (A) CM-injured L1210 cells incubated in DMEM-G $(O)$ or $10 \mathrm{mM} D M E M+G(\triangle)$. Release during first incubation $(24 \mathrm{~h})$ was $15 \%$. (B) L1210 cells incubated with CM for the number of hours shown were removed and reincubated in DMEM-G or $10 \mathrm{mM} D M E M+G$ for $6 \mathrm{~h}$. Release during first incubations was: $0-10 \mathrm{~h}, 12 \% ; 0-20 \mathrm{~h}, 17 \% ; 0-30 \mathrm{~h}, 21 \%$. (C) L1210 cells incubated alone (uninjured L1210 cells) or with CM (injured L1210 cells) were removed and maintained in $30 \mathrm{mM}$ DMEM $+\mathrm{G}$ for the number of hours shown and then washed and reincubated in DMEM-G or $10 \mathrm{mM}$ $\mathrm{DMEM}+\mathrm{G}$ for $6 \mathrm{~h}$. Release during the first incubation $(22 \mathrm{~h})$ was $12 \%$ for CM-injured L1210 cells, $10 \%$ for uninjured L1210 cells. 


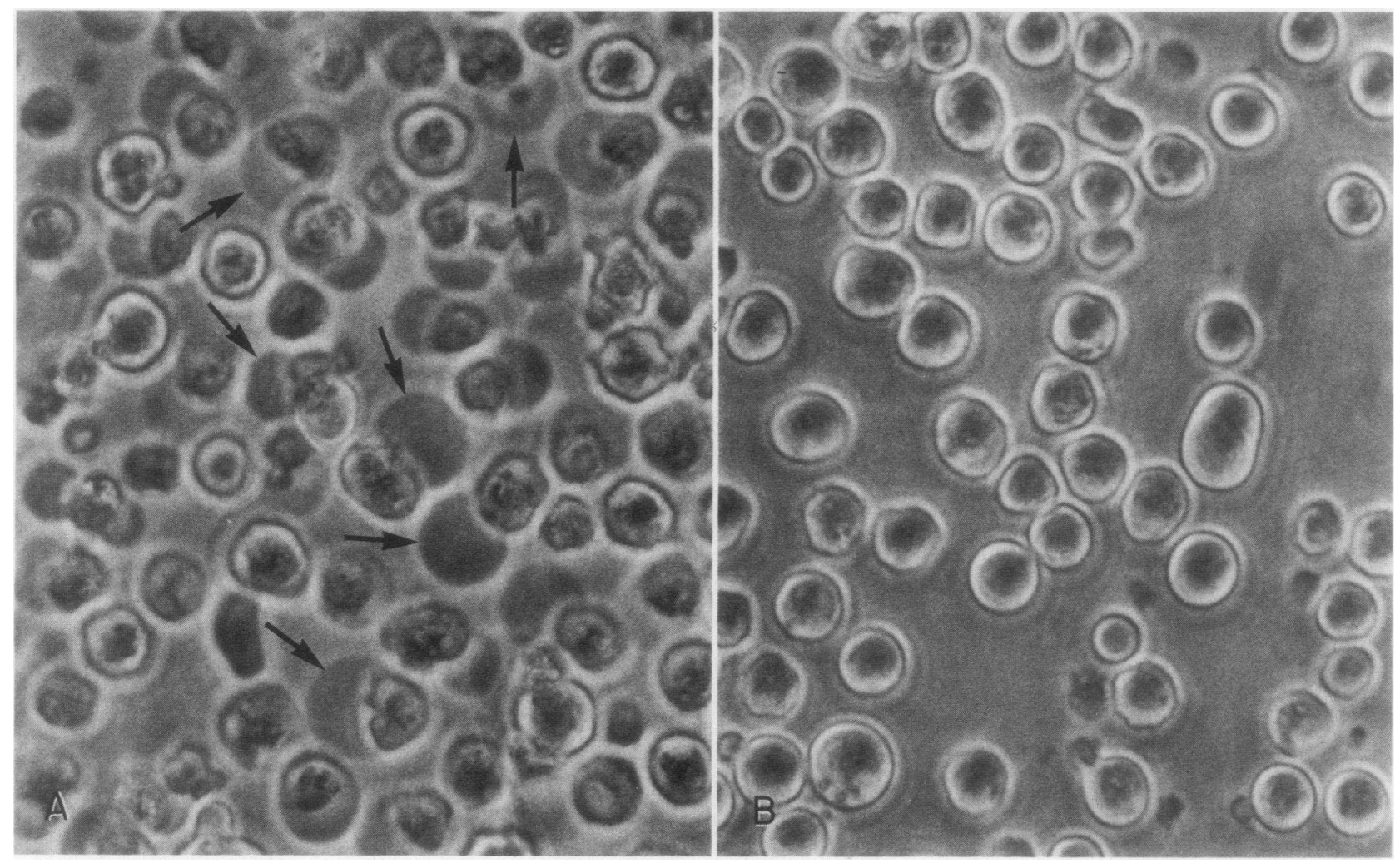

FIGURE 4 Phase-contrast micrographs of L1210 cells which were incubated for $20 \mathrm{~h}$ with CM then removed and reincubated in DMEM-G (A) or $5 \mathrm{mM} \mathrm{DMEM}+\mathrm{G}$ (B) for $2 \mathrm{~h}$. Without glucose many CM-injured L1210 cells have developed acentric blebs (arrows), a sign of cellular injury. No significant blebbing has occurred in medium containing glucose $(\mathrm{B}) . \times 200$.

after sufficient time for transfer of maximal injury, failed to grow in fresh medium for an additional $50 \mathrm{~h}$. Likewise, these injured, nonreplicating cells remained dependent on glucose for at least $40 \mathrm{~h}$ after removal from CM (Fig. 3C). Again, it is apparent that CM-induced injury lasts many hours beyond the period during which it is delivered.

Effect of other sugars and substrates and their concentrations on injured L1210 cell death. A survey of the naturally occurring sugars was undertaken to determine if the glucose requirement of injured L1210 cells could be supplied by other compounds. This approach might give information on what cellular function glucose supported to maintain viability of injured L1210 cells. The compounds were added to DMEM-G at 5 and $50 \mathrm{mM}$ and the effect of preventing death of CM-injured L1210 cells was measured. Of the hexoses tested (L-arabinose, D-fructose, L-fucose, D-galactose, D-glucose, D-mannose), only glucose and mannose at 5 or $50 \mathrm{mM}$ and fructose at $50 \mathrm{mM}$ prevented death. None of the pentoses (D-ribose, D-xylose), aminosugars (D-galactosamine, D-glucosamine, D-mannosamine), nucleotide sugars (guanosine $5^{\prime}$-diphospho-D-mannose, uridine 5'-diphospho-D-glucose), or substrates for mito- chondrial oxidation (pyruvate, glycerol) prevented death. None of the compounds were toxic for uninjured L1210 cells at $50 \mathrm{mM}$. Thus, the glucose requirement of injured L1210 cells was selective. It was not because of increased osmolality of DMEM-G upon glucose addition because other hexoses at the same concentrations had no effect.

The effect of varying the concentration of glucose, mannose, and fructose was studied. Injured L1210 cells survived for $6 \mathrm{~h}$ with $0.5 \mathrm{mM}$ glucose or mannose (Fig. $5 \mathrm{~A})$. With limiting concentrations the dose-response curves of glucose and mannose were virtually superimposable (Fig. 5A). Because a higher concentration of fructose was required, we suspected that this might have been caused by contamination of the fructose sample with glucose. When the sample was analyzed for purity by gas chromatography, it was found to contain $<0.5 \%$ of contaminants which had the same retention time as $\alpha$ - and $\beta$-D-glucose. There was no mannose detectable. The dose-response curve for fructose (Fig. 5B) showed that $\sim 25 \mathrm{mM}$ was required under the same conditions as for glucose and mannose (Fig. $5 \mathrm{~A})$. That would mean that the concentration of contaminating glucose was $\sim 0.13 \mathrm{mM}$, a concentration 

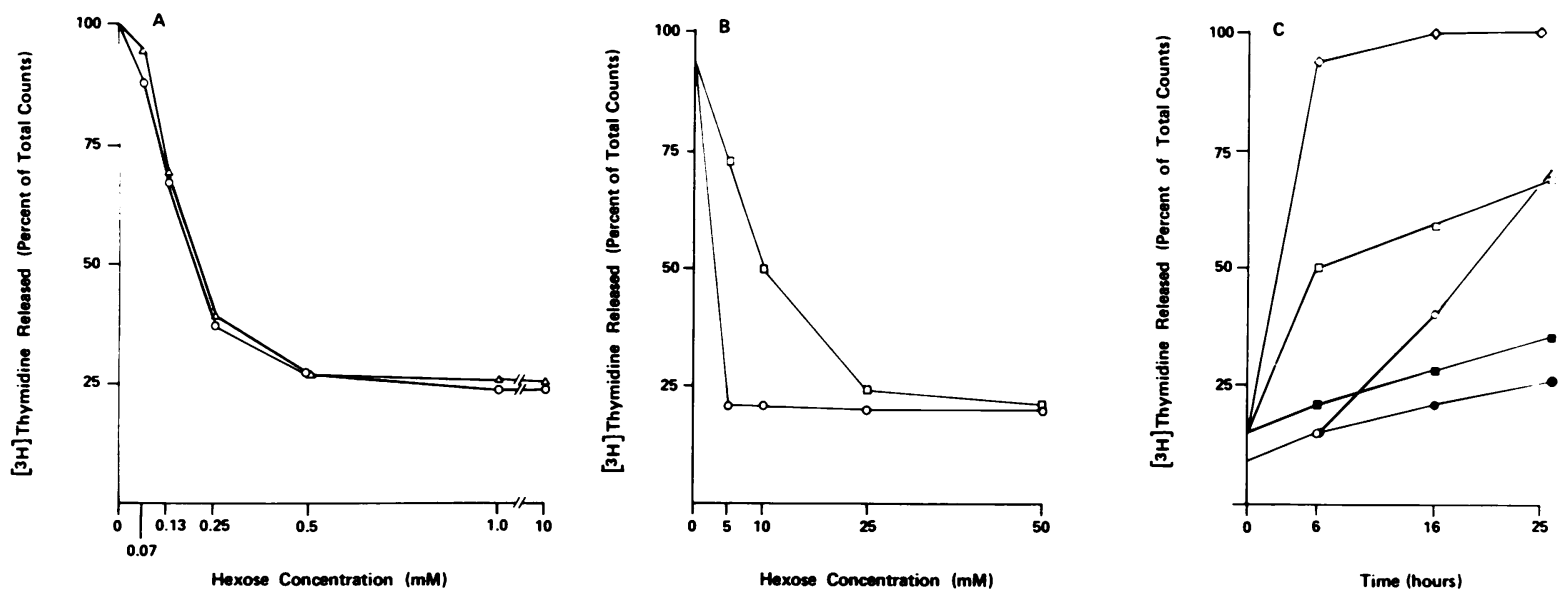

FIGURE 5 Effect of hexose concentration on maintaining viability of CM-injured L1210 cells. (A) CM-injured L1210 cells incubated for $6 \mathrm{~h}$ in DMEM +G $(O)$ or DMEM + mannose $(\triangle)$ at the concentrations shown. Release during the first incubation $(22 \mathrm{~h})$ was $21 \%$. (B) CM-injured L1210 cells incubated for $6 \mathrm{~h}$ in DMEM $+\mathrm{G}(\mathrm{O})$ or DMEM + fructose $(\square)$ at the concentrations shown. Release during the first incubation $(24 \mathrm{~h})$ was $16 \%$. (C) Kinetics of $\left[{ }^{3} \mathrm{H}\right]$ thymidine release for experiment shown in B. $(\diamond)$, DMEM-G; $(\square), 10 \mathrm{mM}$ DMEM + fructose; ( $)$, $25 \mathrm{mM}$ DMEM + fructose. And another experiment with CM-injured L1210 cells: (O), $0.5 \mathrm{mM} \mathrm{DMEM}+\mathrm{G} ;(\bigcirc)$, $10 \mathrm{mM}$ DMEM +G; first incubation $(25 \mathrm{~h})$ release was $23 \%$.

which, based on the results in Fig. 5A, was too low to prevent death. When the time-course of the death-preventing effect of glucose and fructose was measured at limiting concentrations, a distinct difference emerged. Limiting glucose $(0.5 \mathrm{mM})$ maintained viability for $6 \mathrm{~h}$ but between 6 and $25 \mathrm{~h}$, injured L1210 cells began to die (Fig. 5C). This suggested that the small amount of glucose present was exhausted, and once this occurred the injured cells began to die. With fructose at $25 \mathrm{mM}$ this did not occur, and at $10 \mathrm{mM}$, after an initial wave of death between $0-6 \mathrm{~h},\left[{ }^{3} \mathrm{H}\right]$ thymidine release paralleled spontaneous release for the next $19 \mathrm{~h}$ (Fig. 5C). Thus, it did not appear that the small amount of contaminating glucose in the fructose preparation accounted for the effect but that fructose itself prevented injured L1210 cell death and did so at a much higher concentration compared to glucose and mannose. These data were of great interest because they correlated directly with glycolysis of glucose, mannose, and fructose by other mouse ascites cells (Krebs-2 ascites) studied by Yushok (22). He found that the maximal rates (anaerobic glycolysis) of glucolysis and mannolysis were concentration independent to very low levels $(0.5 \mathrm{mM})$. In contrast, the rate of fructolysis was concentration dependent in a linear fashion between 1 and $15 \mathrm{mM}$ at which point it reached maximum. The maximal rates for the three sugars were similar. Thus the hexose requirement of injured L1210 cells correlated directly with the ability of other mouse ascites cells to use the same hexoses as glycolytic substrates.

Inhibition of glycolysis correlates with death of CM-injured L1210 cells. If glycolysis of glucose and mannose is required for survival of injured L1210 cells, then an inhibitor of glycolysis should prevent their effects. 2-deoxy-D-Glucose (2DG) competitively inhibits glycolysis at the phosphohexose isomerase step (23). We found that 2DG inhibited the ability of glucose and mannose to maintain viability of injured L1210 cells and that this inhibition was concentration dependent for both substrate and inhibitor (not shown). A substrate to inhibitor molar ratio (1:10) was chosen which resulted in almost complete reversal of the death preventing effect of glucose and mannose (Table II). Under these conditions L1210 cell aerobic glycolysis was completely inhibited (Table II). In the latter experiment, it was necessary to use uninjured L1210 cells because when injured cells died in the presence of 2DG, lactate production ceased. Inhibition of uninjured L1210 cell glycolysis by 2DG was not a result of cell death because trypan blue cell counts showed complete viability during and after glycolysis incubations. Although the correlation between glycolysis and survival of CMinjured L1210 cells supports a causal relationship between the two phenomena, other metabolic pathways must be considered as well. For example, mammalian cell glycosylation reactions require glucose or mannose and are inhibited by 2DG (24).

The Pasteur effect in injured L1210 cells. As we began to measure aerobic glycolysis of injured L 1210 cells we noted that the rates were always considerably higher than those of the control, uninjured L1210 cells. Increased glycolysis would occur if respiration were inhibited in a way that did not effect the cytoplasmic glycolytic reactions. If macrophage injury inhibited 
TABLE II

Correlation between Hexose Requirement of CM-injured L1210 Cells and Aerobic Glycolysis of Uninjured L1210 Cells

\begin{tabular}{|c|c|c|c|}
\hline \multicolumn{2}{|c|}{ Additions to DEM - G* } & \multirow{2}{*}{$\frac{\text { Experiment } 1 \ddagger}{\left[{ }^{3} \mathrm{H}\right] \text { Thymidine released }}$} & \multirow{2}{*}{$\frac{\text { Experiment } 2 \S}{\text { Lactate produced }}$} \\
\hline Substrate & Inhibitor & & \\
\hline & & $\%$ total counts & $\mu \mathrm{mol} / \mathrm{h} \cdot 10^{-5} \mathrm{cells}$ \\
\hline - & - & 87 & 0 \\
\hline - & $2 \mathrm{DG}$ & 83 & 0 \\
\hline Glucose & - & 17 & 24 \\
\hline Mannose & - & 17 & 20 \\
\hline Glucose & $2 \mathrm{DG}$ & 78 & 0 \\
\hline Mannose & $2 \mathrm{DG}$ & 74 & 0 \\
\hline
\end{tabular}

* Glucose and mannose concentrations were $2 \mathrm{mM}$; 2DG concentration was $20 \mathrm{mM}$.

$\$$ First incubation lasted $24 \mathrm{~h}$. Release during first incubation $=23 \%$. Second incubation lasted $6 \mathrm{~h}$.

\$ Log-phase L1210 cells were incubated in DMEM - G with $2 \%$ dialyzed human serum plus substrates and/or inhibitor as shown. Glycolysis rates were calculated from triplicate samples taken at $0,2,4$, and $6 \mathrm{~h}$. The rates were linear for glucose and mannose during the 6-h incubation. Cell counts at the end of the 6 -h incubation showed $>95 \%$ viability in all experimental groups.

respiration selectively, one could predict that injured L1210 cells would lose their Pasteur effect (depression of glycolysis upon admission of oxygen to anaerobically cultured cells) and exhibit an inappropriately high rate of glycolysis with oxygen present. Glycolysis of in- jured L1210 cells conformed to this prediction (Fig. 6 ). The rates of aerobic and anaerobic glycolysis of injured L1210 cells were the same and this rate was similar to the anaerobic rate for uninjured cells. The Pasteur effect for uninjured L1210 cells was greater than a threefold decrease, a clear difference compared to injured L1210 cells. This experiment was performed five times and gave the same results presented in Fig. 6 . The amount of lactate produced by contaminating $\mathrm{CM}$ in the injured L1210 cell suspension was determined by appropriate controls and was found to be negligible.

Respiration of injured L1210 cells. Results presented in Table III show that endogenous respiration of CM-injured L1210 cells was very low. Depression of respiration was found only in L1210 cells previously contacted by CM. It was not a direct effect of ET or MAF because respiration of $\mathrm{L} 1210$ cells cultured alone for the same time period with ET or MAF was unaffected. Respiratory depression was not an artifact of cell death as viability counts after all respiration measurements showed $>90 \%$ living cells. Moreover, after respiration measurements injured L1210 cells were recultured in $10 \mathrm{mM} D M E M+G$ for $24 \mathrm{~h}$ without significant loss of viability. Long-term $(3 \mathrm{~h})$ respiration measurements using manometry showed the same depression of CM-injured L1210 cells (not shown). The medium used in these experiments (Krebs-Ringer phosphate buffer containing glucose and serum) supports injured L1210 cell viability for at least $20 \mathrm{~h}$.

That CM-induced inhibition of $\mathrm{O}_{2}$ consumption re-

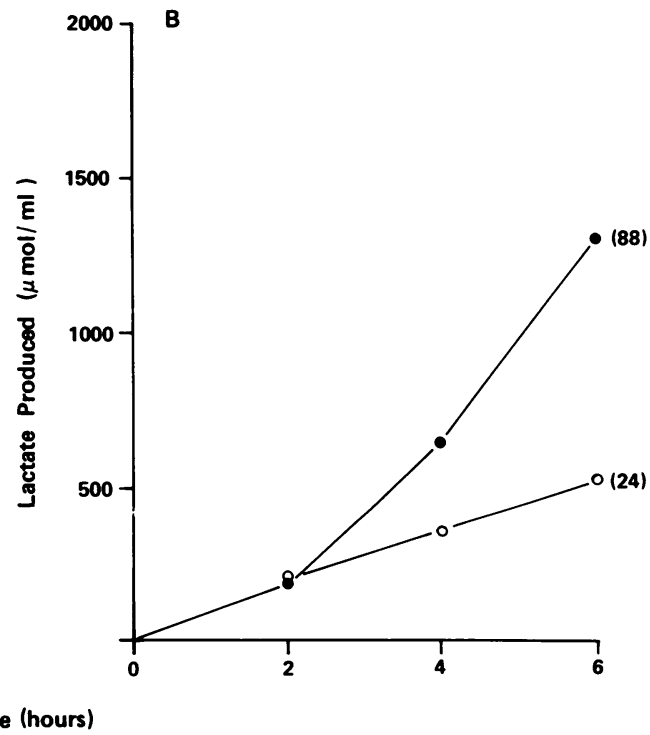

Figure 6 Aerobic $(O)$ and anaerobic $(O)$ glycolysis of CM-injured and uninjured L1210 cells. (A) L1210 cells which had been incubated for $20 \mathrm{~h}$ with CM before glycolysis measurements. (B) L1210 cells which had been incubated for $20 \mathrm{~h}$ without macrophages before glycolysis measurements. Numbers in parentheses are maximal rates of lactate production expressed as micromoles per hour per $10^{5}$ cells. 
TABLE III

Endogenous Respiration of CM-injured L1210 Cells

\begin{tabular}{clc}
$\begin{array}{c}\text { No. of } \\
\text { experiments }\end{array}$ & \multicolumn{1}{c}{ L1210 cells cultured with:* } & O consumptiont \\
\hline & & $\mu l / h \cdot 10^{-6}$ cells \\
6 & Alone & $7.4 \pm 0.3$ \\
4 & Alone + ET $(200 \mathrm{ng} / \mathrm{ml})$ & $7.2 \pm 0.4$ \\
2 & Alone + MAF $(10 \% \mathrm{vol} / \mathrm{vol})$ & $7.2 \pm 0.9$ \\
4 & SM & $6.9 \pm 0.7$ \\
6 & CM & $1.1 \pm 0.1$ \\
2 & CM (MAF) & $1.7 \pm 0.4$ \\
3 & Alone (oligomycin inhibited) $\S$ & $0.9 \pm 0.1$ \\
3 & Alone (antimycin A inhibited) $\S$ & $0.3 \pm 0.1$ \\
\hline
\end{tabular}

* For these experiments, L1210 cells were cultured alone or with macrophages for $24-40 \mathrm{~h}$ before respiration measurements.

\$ Values are the mean $\pm \mathrm{SEM}$ for the number of experiments shown.

$\$$ The effects of oligomycin and antimycin A were determined by injection into the respiration vessel to a final concentration of 0.1 and $0.01 \mu \mathrm{M}$, respectively. Previous experiments showed that these concentrations produced maximal inhibition of uninjured $\mathrm{L} 1210$ cell respiration at $2 \times 10^{6}$ cells $/ \mathrm{ml}$.

flects L1210 cell mitochondrial dysfunction is supported by the fact that the bulk of $\mathrm{O}_{2}$ consumed by uninjured L1210 cells was inhibited by either antimycin A or oligomycin (Table III). Antimycin A specifically inhibits the electron transport chain at the level of cytochrome $b(25)$ and oligomycin acts on the mitochondrial ATP synthetase complex (26). Maximal inhibition by antimycin $\mathrm{A}$ reflects total mitochondrial $\mathrm{O}_{2}$ consumption whereas oligomycin inhibits that portion of mitochondrial respiration coupled to phosphorylation (26). It was interesting that the degree of inhibition by $\mathrm{CM}$
(85\%) was almost the same as maximal inhibition by oligomycin (87\%). These findings provided an apparent explanation for the death-preventing effect of glucose on injured L1210 cells. Because macrophage injury almost completely inhibited cellular respiration, and hence mitochondrial ATP production, injured L1210 cells became dependent on glycolysis for chemical energy. It is unlikely that endogenous sources of glucose, either from glycogen or via gluconeogenesis provided sufficient substrate for glycolysis because lactate was not produced when uninjured L1210 cells were incubated in DMEM-G (Table II).

The kinetics of L1210 cell respiratory inhibition by $\mathrm{CM}$ was measured. There was a time-dependent inhibition that reached maximum between 10 and $20 \mathrm{~h}$ (not shown). This correlated with the time of exposure to $\mathrm{CM}$ required to produce near complete death of L1210 cells in DMEM-G (Fig. 3B).

CM-induced respiratory inhibition in other neoplastic cells. To examine whether CM-induced mitochondrial injury was unique for L1210 cells, a group of neoplastic cell lines was selected which differed in a number of characteristics as shown in Table IV. Injury by $\mathrm{CM}$ led to inhibition of $\mathrm{O}_{2}$ consumption in all cell lines tested regardless of species or tissue of origin, inducing carcinogenic agent, or whether the neoplastic cells arose in vivo or were transformed in vitro (SV40 HE-1). Although endogenous respiration of each cell line was inhibited, some like L1210 did not die, provided ample glycolysis substrate was present, whereas others (e.g., P815) were readily killed in the presence of nonlimiting glucose supply. In the latter case, P815 cells were removed from $\mathrm{CM}$ after a 10 -h coculture and $\mathrm{O}_{2}$ consumption was measured before cell death occurred. As shown in Table IV, endogenous respiration of the different uninjured cell lines varied widely.

TABLE IV

Respiratory Inhibition of Neoplastic Cells by CM

\begin{tabular}{|c|c|c|c|c|}
\hline \multirow[b]{2}{*}{ Cell line* } & \multirow[b]{2}{*}{ Origin of cell line } & \multirow[b]{2}{*}{ Oncogenic agent } & \multicolumn{2}{|c|}{$\begin{array}{c}\mathrm{O}_{2} \text { consumption } \\
\text { of neoplastic cells after } \\
\text { culture with: } \downarrow\end{array}$} \\
\hline & & & Alone & CM \\
\hline & & & \multicolumn{2}{|c|}{$\mu l / h \cdot 10^{-6}$ cells } \\
\hline L1210 & Mouse (DBA/2) lymphoblastic leukemia & Methylcholanthrene & $7.2 \pm 0.4$ & $1.1 \pm 0.1$ \\
\hline P815 & Mouse (DBA/2) mastocytoma & Methylcholanthrene & $5.9 \pm 0.3$ & $2.0 \pm 0.5$ \\
\hline S180 & Mouse (outbred) sarcoma & Unknown & $14.2 \pm 0.9$ & $1.3 \pm 0.4$ \\
\hline TLX-9 & Mouse (C57B1) thymic lymphoma & $\mathrm{X}$ ray & 2.8 & 0.1 \\
\hline L10 & Guinea pig (strain 2) hepatoma & Diethylnitrosamine & $16.9 \pm 3.6$ & $3.6 \pm 1.7$ \\
\hline SV40 HE-1 & Transformed hamster (LSH) embryo cell line & SV40 virus & $10.0 \pm 2.1$ & $1.2 \pm 0.2$ \\
\hline
\end{tabular}

* All maintained in vitro except for L10 cells which were harvested from strain 2 guinea pig ascites.

‡ Culture periods before endogenous respiration measurements were 24-40 h except for P815 cell experiments $(10 \mathrm{~h})$. SV40 HE-1 cells adhere to plastic and were removed by trypsin $(0.25 \%$ in phosphate-buffered saline, Difco Laboratories) treatment for $5 \mathrm{~min}$. Values are the mean $\pm \mathrm{SEM}$ for at least three experiments except for TLX-9 cells (one experiment). 
However, the degree of inhibition by $\mathrm{CM}$ was quite constant (80-90\% excluding P815 cells which were exposed to CM for only $10 \mathrm{~h}$ ). This suggested that the different cell lines may be uniformly susceptable to C.M-induced mitochondrial injury.

\section{DISCUSSION}

These results demonstrate that CM inhibit L1210 cell mitochondrial function. This could occur by either a direct attack on mitochondria or indirectly by interference at another locus such as the plasma membrane. It will be important to determine whether mitochondrial structure is altered by macrophage injury or whether a specific enzyme is inhibited. Alternatively, the mitochondrial enzyme systems may be relatively intact, but substrate for oxidation or an essential cofactor may be unavailable as a result of defective transport or possibly loss from the mitochondria. What macrophage effector molecule(s) causes inhibition and how it is brought about is unknown. The complexity of the mitochondrion presents numerous potential sites for inhibition. However, it is worth pointing out in a general way that the one property which governs many mitochondrial reactions is the integrity of the inner mitochondrial membrane. Therefore, macrophage-derived products which have membrane perturbing effects would appear to be prime candidates as effector molecules.

Whether mitochondrial injury per se is capable of producing cytostasis of neoplastic cells is open to question. A eukaryotic cell, Saccharomyces cerevisiae, which through mutation has lost the ability to respire and hence cannot produce chemical energy from its mitochondria, nevertheless, retains mitochondrial function (27). For example, adenine nucleotides are translocated between cytoplasm and mitochondrial matrix. Specific inhibition of the adenine nucleotide translocator by either a second mutation or by the plant poison, bongkrekic acid, leads to loss of cell division (28). Hence, a mitochondrial function, as yet undefined, appears to be required for cell growth.

A group of mammalian cell mutants has been described which are respiration-deficient and like the yeast mutants produce ATP solely by glycolysis (29). It was shown that a mutation affecting the cytochrome chain led to almost complete cessation of Krebs cycle reactions $(30,31)$. As a consequence, the mutant cells became auxotrophic for a nonessential amino acid (aspartate) which is synthesized via the Krebs cycle intermediate, oxaloacetate. Addition of asparagine (presumably transported better than aspartate) to the culture medium allowed the mutant cells to grow at a rate similar to the wild-type parent cells. The examples cited demonstrate that although there is no doubt that some eukaryotic cells (including mammalian cells) can produce sufficient energy from glycolysis to support cell division, mitochondrial function is still a fundamental requirement for replication.

Probably the earliest metabolic defect in macrophageinjured neoplastic cells is inhibition of DNA synthesis. It was shown that by $4-6 \mathrm{~h}$ after contact with $\mathrm{CM}$, there was a significant decrease in $\left[{ }^{3} \mathrm{H}\right]$ thymidine uptake by injured mouse lymphoma cells (32). Our results show that it takes $\sim 20 \mathrm{~h}$ contact with $\mathrm{CM}$ for maximal inhibition of endogenous respiration. However, by $10 \mathrm{~h}$ there is a definite effect involving mitochondria because endogenous respiration had decreased by nearly $50 \%$ (not shown). This suggests that mitochondria may be injured within a few hours after contacting CM and leaves open the possibility that mitochondrial injury may actually preceed inhibition of DNA synthesis.

A striking feature of $\mathrm{CM}$-induced cytostasis is its persistence despite removal from $\mathrm{CM}$ and resupplying the injured cells with fresh nutrients (Fig. 2). This suggests that the injury which produces cytostasis is somehow perpetuated or cannot be easily repaired. We found that CM-injured L1210 cells remained dependent on glucose for survival for at least $40 \mathrm{~h}$ after removal from C.M (Fig. 3C). It is likely therefore, that mitochondrial injury lasts for at least $2 \mathrm{~d}$ after it has reached maximum and this correlates well with the persistence of cytostasis (Fig. 2).

Can mitochondrial injury cause death of neoplastic cells? Based on the maximal inhibition of endogenous respiration of L1210 cells by oligomycin (Table III), which was $87 \%$ of total, we can presume that this fraction of oxygen consumption was mitochondrial and moreover, that it was coupled to phosphorylation. This assumption follows from the observations that: $(a)$ Oligomycin specifically inhibits only mitochondrial oxygen consumption and not other cellular oxygen consuming reactions (25). (b) Oligomycin inhibits mitochondrial oxygen consumption which is coupled to phosphorylation by virtue of its site of action - the protein complex responsible for transducing the proton electrochemical gradient established by the cytochrome oxidoreduction reactions into chemical energy (26). Oligomycin inhibits respiration of intact cells at concentrations similar to those employed with preparations of mitochondria (33). Cytotoxic macrophages inhibit L1210 cell endogenous respiration by $\sim 85 \%$ (Table III). Therefore, at least $75 \%$ of phosphorylating respiration must be shut off and this could be as high as $98 \%$. As a consequence the rate of glycolysis increases about threefold, close to the rate observed when respiration is inhibited by anaerobic conditions (Fig. 6). The source of ATP production is now glycolysis. Deletion of glycolytic substrate (glucose, mannose, or fructose) from the environment leaves the injured L 1210 cell without an energy source. At $37^{\circ} \mathrm{C}$ in medium with a composition similar to extracellular fluid, mammalian 
cells require a continuing supply of ATP for energy consuming ion translocations. If ATP is not supplied, water enters the cell, as the system approaches the Gibbs-Donnan equilibrium, and the cell bursts (34). Death of uninjured L1210 cells caused by energy deprivation was produced by anaerobic incubation at $37^{\circ} \mathrm{C}$ in DMEM-G. ${ }^{3}$ Within $6 \mathrm{~h}$ viability dropped to $<1 \%$. Addition of glucose to DMEM-G completely prevented death. A similar effect was seen when cultured cells were poisoned with both cyanide, at a concentration inhibitory to respiration, and an inhibitor of glycolysis, iodoacetate (34). Moreover, Chinese hamster respiration-deficient mutant cells die within hours if glucose is exhausted from their medium (30). By analogy it seems likely that energy deprivation leads to CM-injured L1210 cell death in DMEM-G. Consequently, maintenance of glycolysis assumes paramount importance in determining the life or death outcome of the injured cell. Factors which influence glycolysis (35) such as $\mathrm{pH}$, glucose transport, inorganic phosphate concentration, and the activities of the glycolytic enzymes could determine whether or not macrophageinjured cells die. With regard to the susceptibility and resistance of various neoplastic cells to macrophagemediated cytolysis, inherent differences in their ability to maintain glycolysis at a high rate may be a determining factor.

\section{ACKNOWLEDGMENTS}

We thank M. Sedlar, R. Christensen, and J. Brisbay for excellent technical assistance, and K. Bryan and G. McNulty for typing the manuscript. We are indebted to Doctors A. Deiss, H. Chapman, Jr., C. Smith, and G. Cartwright for their critical reviews. We thank Dr. J. Weinberg for pointing out to us that proteases cause release of $\left[{ }^{3} \mathrm{H}\right]$ thymidine from dead lymphoma cells.

This work was supported by the Veterans Administration and by National Institutes of Health grant CA 14045.

\section{REFERENCES}

1. Evans, R., and P. Alexander. 1976. Mechanisms of extracellular killing of nucleated mammalian cells by macrophages. In Immunobiology of the Macrophage. D. S. Nelson, editor. Academic Press, Inc., New York. 535-576.

2. North, R. J. 1978. The concept of the activated macrophage. J. Immunol. 121: 806-809.

3. Osserman, E. F., M. Klockars, J. Halper, and R. C. Fischel. 1973. Effects of lysozyme on normal and transformed mammalian cells. Nature (Lond.). 243: 331-335.

4. Hibbs, J. B., Jr. 1974. Heterocytolysis by macrophages activated by Bacillus Calmette-Guerin: lysosome exocytosis into tumor cells. Science (Wash. D. C.). 184: 468-471.

5. Ferluga, J., H. U. Schorlemmer, L. C. Baptista, and A. C. Allison. 1978. Production of the complement cleavage product, $\mathrm{C} 3 \mathrm{a}$, by activated macrophages and its tumorolytic effects. Clin. Exp. Immunol. 31: 512-517.

6. Nathan, C. F., S. C. Silverstein, L. H. Brukner, and Z. A.

${ }^{3}$ Granger, D. L. Unpublished data.
Cohn. 1979. Extracellular cytolysis by activated macrophages and granulocytes. II. Hydrogen peroxide as a mediator of cytotoxicity. J. Exp. Med. 149: 100-113.

7. Weinberg, J. B., H. A. Chapman, Jr., and J. B. Hibbs, Jr. 1978. Characterization of the effects of endotoxin on macrophage tumor cell killing. J. Immunol. 121: 72-80.

8. Law, L. W., T. B. Dunn, P. J. Boyle, and J. H. Miller. 1949. Observations on the effect of a folic acid antagonist on transplantable lymphoid leukemia in mice. J. Natl. Cancer Inst. 10: 179- 192.

9. Hibbs, J. B., Jr., R. R. Taintor, H. A. Chapman, Jr., and J. B. Weinberg. 1977. Macrophage tumor killing: influence of the local environment. Science (Wash. D. C.). 197: 279-282.

10. Klein, G., and P. Perlmann. 1963. In vitro cytotoxic effect of isoantibody measured as isotope release from labelled target cell DNA. Nature (Lond.). 199: 451-453.

11. Reif, A. E., C. M. Robinson, and J. S. Incze. 1976. Assay of immune cytolysis of lymphocytes and tumor cells by automatic determination of cell volume distribution. $\mathrm{Im}$ munology. 33: 69-80.

12. Hohorst, H. 1965. L-(+)-Lactate determination with lactic dehydrogenase and DPN. In Methods of Enzymatic Analysis. H. Bergmeyer, editor. Academic Press, Inc., New York. 266-270.

13. Sennello, L. T. 1971. Gas chromatographic determination of fructose and glucose in syrups. J. Chromatogr. 56: 121-125.

14. Skipper, H. E., F. M. Schabel, Jr., and W. S. Wilcox. 1964. Experimental evaluation of potential anticancer agents. XIII. On the criteria and kinetics associated with "curability" of experimental leukemia. Cancer Chemother. Rep. 35: 1-111.

15. Hibbs, J. B., Jr., L. H. Lambert, Jr., and J. S. Remington. 1971. Resistance to murine tumors conferred by chronic infection with intracellular protozoa. Toxoplasma gondii and Besnoitia jellisoni. J. Infect. Dis. 124: 587-592.

16. Nathan, C. F., and W. D. Terry. 1975. Differential stimulation of murine lymphoma growth in vitro by normal and BCG-activated macrophages. J. Exp. Med. 142: 887902.

17. Krahenbuhl, J. L., and L.H. Lambert, Jr. 1975. Cytokinetic studies of the effects of activated macrophages on tumor target cells. J. Natl. Cancer. Inst. 54: 1433-1437.

18. Doe, W. F., and P. M. Henson. 1978. Macrophage stimulation by bacterial lipopolysaccharides. I. Cytolytic effect on tumor target cells. J. Exp. Med. 148: 544-556.

19. Hibbs, J. B., Jr. 1976. The macrophage as a tumoricidal effector cell: a review of in vivo and in vitro studies on the mechanism of the activated macrophage nonspecific cytotoxic reaction. In The Macrophage in Neoplasia. M. Fink, editor. Academic Press, Inc., New York. 83-111.

20. Currie, G. A. 1978. Activated macrophages kill tumor cells by releasing arginase. Nature (Lond.). 273: 758-759.

21. Stadecker, M. J., J. Calderon, M. L. Karnovsky, and E. R. Unanue. 1977. Synthesis and release of thymidine by macrophages. J. Immunol. 119: 1738-1743.

22. Yushok, W. D. 1959. Metabolism of ascites tumor cells. I. Rate of glycolysis and competitive utilization of fructose, mannose and glucose. Cancer Res. 19: 104-111.

23. Wick, A. N., D. R. Drury, H. I. Nakada, and J. B. Wolfe. 1957. Localization of the primary metabolic block produced by 2-deoxyglucose. J. Biol. Chem. 224: 963-969.

24. Hughes, R. C., A. Meager, and R. Nairn. 1977. Effect of 2-deoxy-d-glucose on the cell-surface glycoproteins of hamster fibroblasts. Eur. J. Biochem. 72: 265-273.

25. Slater, E. C. 1967. Application of inhibitors and un- 
couplers for a study of oxidative phosphorylation. Methods Enzymol. 10: 48-57.

26. Racker, E. 1976. Lecture 4: the coupling device. In A New Look at Mechanisms in Bioenergetics. Academic Press, Inc., New York. 67-87.

27. Groot, G. S. P., L. Kovac, and G. Schatz. 1971. Promitochondria of anaerobically grown yeast. V. Energy transfer in the absence of an electron transfer chain. Proc. Natl. Acad. Sci. U. S. A. 68: 308-311.

28. Kovac, L., J. Kolarov, and J. Subik. 1977. Genetic determination of the mitochondrial adenine nucleotide translocation system and its role in the eukaryotic cell. Mol. Cell. Biochem. 14: 11-14.

29. Donnelly, M., and I. E. Scheffler. 1976. Energy metabolism in respiration-deficient and wild type Chinese hamster fibroblasts in culture. J. Cell. Physiol. 89: 39-51.

30. DeFrancesco, L., D. Werntz, and I. E. Scheffler. 1975. Conditional lethal mutations in Chinese hamster cells.
Characterization of a cell line with a possible defect in the Krebs cycle. J. Cell. Physiol. 85: 293-305.

31. DeFrancesco, L., I. E. Sheffler, and M. J. Bissell. 1976. A respiration-deficient Chinese hamster cell line with a defect in NADH-coenzyme Q reductase. J. Biol. Chem. 251: 4588-4595.

32. Krahenbuhl, J. L., and J. S. Remington. 1974. The role of activated macrophages in specific and nonspecific cytostasis of tumor cells. J. Immunol. 113: 507-516.

33. Gregg, C. T., J. M. Machinist, and W. D. Currie. 1968. Glycolytic and respiratory properties of intact mammalian cells: inhibitor studies. Arch. Biochem. Biophys. 127: $101-111$.

34. Trump, B. F., and A. U. Arstila. 1975. Cellular reaction to injury. In Principles of Pathobiology. M. F. LaVia and R. B. Hill, Jr., editors. Oxford University Press, New York. 2nd edition. 9-96.

35. Racker, E. 1972. Bioenergetics and the problem of tumor growth. Am. Sci. 60: 56-63. 